\title{
IMachining technology analysis for contour milling
}

\author{
Y. V. Petrakov • A. V. Myhovych \\ Igor Sikorsky Kyiv Polytechnic Institute, Kyiv, Ukraine
}

Received: 20 April 2020 / Accepted: 25 May 2020

\begin{abstract}
Recognizing the practical need to control the cutting process, leading firms in the high-tech market began to offer software products that, in the automatic mode, were said to be able to calculate the optimal cutting mode. Currently, the most advanced technology is called iMachining, which means intelligent Machining. The article presents an analysis of the control, automatically designed in the iMachining Solid CAM module, for machining a test part, the contour of which is formed by two straight circular arcs of a circle. It is shown that when designing control, geometric criteria are used that are associated with the path of shaping, so stabilization of the cutting process is not achieved. A control design method is proposed based on the results of simulation the Material Removal Rate (MRR), which allows stabilizing the cutting process.

Keywords: control of cutting, iMachining, stabilization MRR, contour milling on CNC Machine
\end{abstract}

\section{Introduction}

Different CAM systems are widely used to create control programs for CNC machines. The practical use of such systems has revealed that they do not take into account the characteristics of the cutting process, especially when machining the complex surfaces of machine parts. The purpose of the cutting mode was entirely entrusted to the programmer-technologist, who assigned the mode from his own experience or the recommendations of the manufacturer of the tools. However, changing the cutting conditions along the shaping trajectory provokes certain conflicts, the solution of which in practice was to assign a mode to the worst-case calculation for the entire trajectory. Thus, the ability of the CNC machine to permanently control any cutting mode parameters was not used at all, leading to a significant loss of productivity.

Therefore, the scientific and technical problems of creating automation systems for the preparation of control programs that automatically solve not only the geometric problem of designing trajectories of shaping, but also the control of the cutting process remains relevant.

\section{Problem status analysis}

Recognizing the practical need to control the cutting process, leading firms in the high-tech market began to offer software products that, in the automatic mode, were said to be able to calculate the optimal cutting mode.

It is known that the control of the cutting mode must be carried out by the following algorithm: first stabilization, then optimization and, if necessary, the correction of the trajectory in the last, clear passage [1]. However, the first attempts to stabilize the cutting mode were realized by the geometric criterion. Thus, Delcam patented a Vortex strategy, which is based on the use of special trochoidal trajectories, whereby a constant cutting angle of the cutter with the workpiece is maintained in the cutting process [2]. It is argued that this ensures the stabilization of cutting conditions, although it is known from the cutting theory, that there is no proportional relationship between the cutting 
force and the cutting angle [3], so the stabilization of the cutting angle cannot lead to stabilization of the main characteristics of the cutting process - force and power. In addition, high-speed machining (HSM) trajectory trajectories have distorted them. Therefore, an additional program called Machine DNA Profiler was created, which, as a result of dynamic tests on specific equipment, gives the necessary conditions for using such control. All this significantly complicates the practical use of the proposed technology [3].

Earlier, company CGTech (USA) developed a software product called Vericut. The main problem addressed by this development is the verification of G-code control programs when simulated in a virtual machine environment for error detection, tool collisions, and more. The package also has an OptiPath module that is able to optimize the cutting mode by adjusting the feed according to the principle: the higher the Material Removal Rate (MRR), the less feed you use [4]. However, no algorithms for such control or MRR determination are provided, and data on the effectiveness of such optimization is clearly insufficient for its practical evaluation.

At the moment, the most common technology is called iMachining, which means intellectual Machining. This technology is implemented in SolidCAM and Siemens NX software.

It is noted that SolidCAM is the only CAM system that does not need to invent or choose the cutting mode. Unique trajectories (unlike the trochoidal ones used by Vortex technology) form complex polymorphic spirals, which is said to maximize contact time of the tool with the workpiece and reduce idle time [5]. In addition, it is claimed that the technology master-module iMachining automatically optimizes the cutting mode, taking into account the material of the workpiece, the cutting process and the machine-tool.

Thus, it is proposed to reduce the range of uncertainty when considering the stiffness of a particular technological machining system by choosing one of 8 possible levels, which adapts design machining to the real conditions. This is how it is proposed to overcome standard problems with spindle and workpiece and tool stiffness, to avoid excessive vibration [6]. The practical use of iMachining technology can increase productivity, although the degree of efficiency will depend on the specific conditions of production [7].

\section{Objective}

Efficiency and capabilities analysis of iMachining technology for stabilization, optimization of the cutting mode in contour milling with end mills.

\section{Statement of the main material}

Some of the declared properties of the iMachining technology were analyzed using a computer experiment of machining a test piece, the contour of which consists of two straight lines and arc circles. Since technology (like all of the above) uses the control method based on a priori information, the essence of the experiment was to compare the design results with those obtained in the simulation process [8]. The simulation is performed by numerical methods and determines the main characteristic of the milling process - Material Removal Rate (MRR).

For the experiment, a trial version of Solid CAM with iMachining [9] was used, with the help of which a control program for milling the contour of the part 1 with a milling cutter 2 was designed (Fig. 1, $a$ ) and the corresponding G-codes were generated (Fig. 1,b).

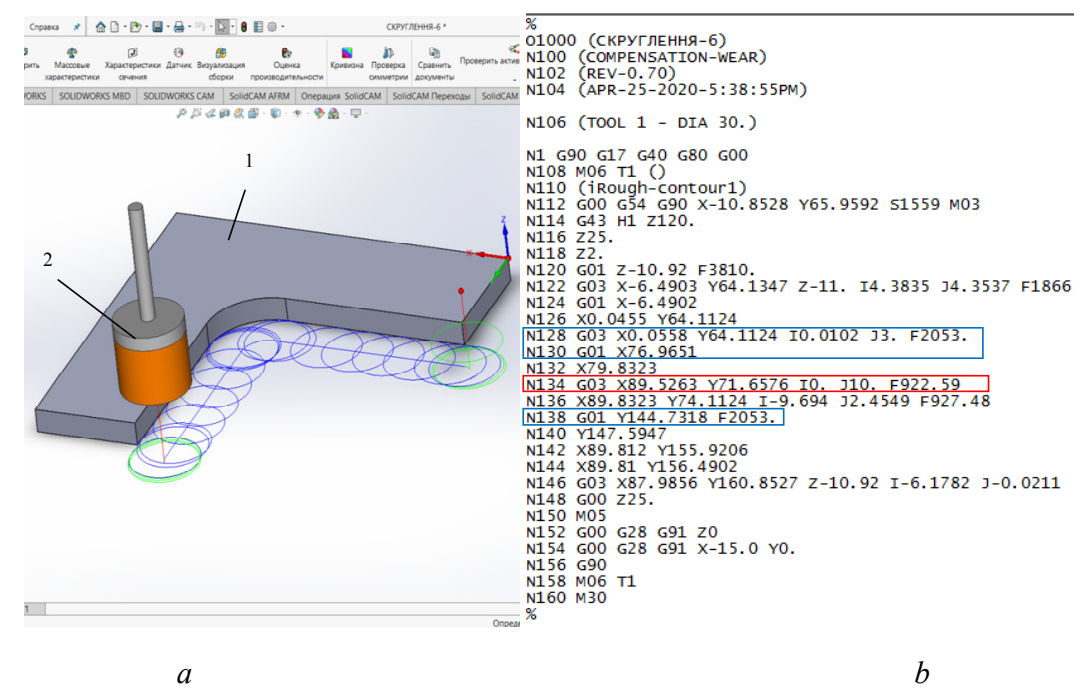

Fig. 1. Design results in iMachining Solid CAM: $a$ - simulation interface; $b$ - G-code of control program 
The following initial data were selected: workpiece - material Steel30, radius of the contour of the workpiece $25 \mathrm{~mm}$, allowance $1.5 \mathrm{~mm}$, thickness $10 \mathrm{~mm}$, end mill $\varnothing 30 \mathrm{~mm}, 6$ teeth, tilt blade $30^{\circ}$, solid A20 Solid carbide. All further design activities were performed on interactive mode.

An analysis of the automatic designed G-code of control program shows that the system has selected HSM mode. The spindle speed is $1559 \mathrm{rpm}$, and the feed at the plan sections is $2053 \mathrm{~mm} / \mathrm{min}$ (see frames 128 and 138), and when machining the cylindrical surface, feed is reduced to $922.59 \mathrm{~mm} / \mathrm{min}$ and $927.48 \mathrm{~mm} / \mathrm{min}$. Moreover, the beginning of the feed change corresponds to the coordinate of the shape-forming trajectory, when the center of the mill enters the arc of the circle, and the end of the change - the point when it exits the arc machining.

To analyze the conformity of cutting process control to the stabilization principle by the criterion of material removal rate (MRR), modeling was performed. The simulation was performed numerically in a specially created program, the interface of which is shown in Fig. 2.

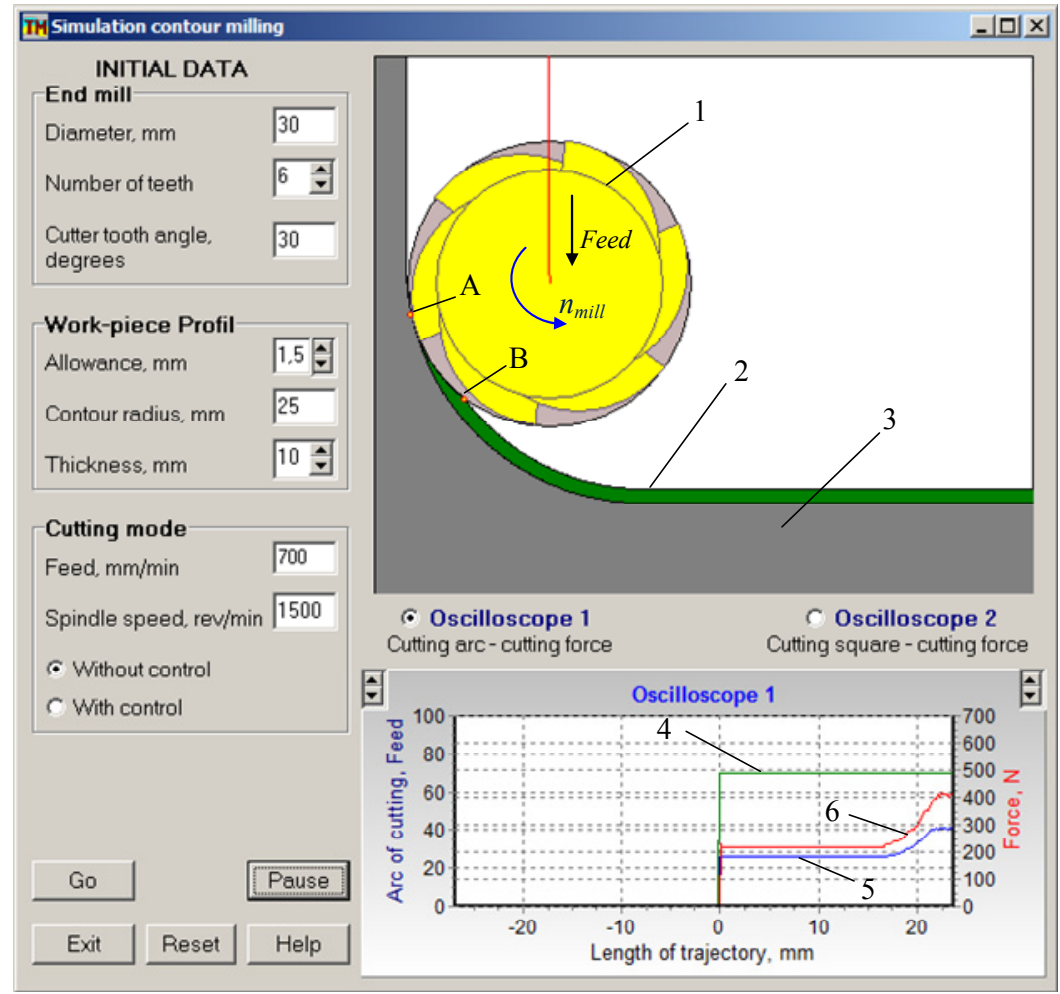

Fig. 2. Simulation program interface

The simulation inputs specified in the left-hand side windows correspond exactly to the input of the milling process that was used to prepare the control program in Solid CAM. When modeling in the graphical window, the motion of the mill 1, which cuts the allowance 2 on the workpiece 3, is reproduced. Due to the numerical algorithm for determining the intersection of the digital array of the workpiece contour and the milling cutter [8], the points of beginning (point A) and end (point B) of cutting arc are determined at each step of simulation.

The feed graphs - line 4, the cutting angle - line 5 and the circumferential component of the cutting force - line 6 appears on the virtual oscilloscope. The cutting angle and feed are measured behind the left axis (the feed value is increased by 10 times), and the circumferential component of the cutting force - along the right axis. All graphs are tied to the movement of the cutter along the shape-forming path - the horizontal axis of the oscilloscope.

The circumferential component of the cutting force is determined numerically by an algorithm that functions according to two nested cycles. In the internal cycle, the area $\delta s_{i}$ of cutting is determined on a separate section of the cutting tooth of the mill:

$$
\delta s_{i}=\frac{F_{\min } \operatorname{Sin} \delta \varphi_{i}}{n_{m} z_{m}}
$$

where $F_{\min }-$ feed $(\mathrm{mm} / \mathrm{min}), \delta \varphi_{i}$ - cutting angle at the tooth site, $n_{m}-$ spindle speed $(\mathrm{rpm}), z_{m}-$ number of cutter teeth.

The transition from the external cycle to the internal cycle is performed by the condition: 


$$
\delta \phi_{i}<\alpha_{p}
$$

where $\alpha_{c}$ - cutting angle, and the elementary cutting angle in a separate area of tooth is calculated by the formula:

$$
\delta \phi_{i}=\alpha_{c}-(i h \tan \beta) / R_{m},
$$

where $h$-step of movement along the width $B$ of the milling, $\beta$-angle of inclination of the mill groove, $R_{m}-$ radius of the mill, $i$ - iteration number in the cycle $(0 \leq i \leq k)$, where $k=B / h$.

The circumferential component of the cutting force is calculated by the empirical formula [10]:

$$
P_{o}=C_{P} \sum_{i=0}^{k}\left(\delta s_{i}\right)^{\alpha},
$$

where CP, $\alpha$ - empirical coefficient and exponent.

Thanks to this algorithm, the program provides the ability to determine the "instantaneous" value of the cutting force on each cutter tooth (Fig. 3,a). To display such an oscillogram on the oscilloscope screen, the interface has a special option - "Oscilloscope 2" (see Fig. 2). In addition, the created program allows performing modeling both with a constant feed and with a feed that changes according to a special control law. The control law is loaded before starting the simulation when the "With control" option is selected on the program interface.

Fig. 3, $b$ shows the integrated simulation results at a constant feed of $700 \mathrm{~mm} / \mathrm{min}$ in the form of oscillograms: line 1 - feed, line 2 - cutting angle, line 3 - circumferential component of the cutting force.

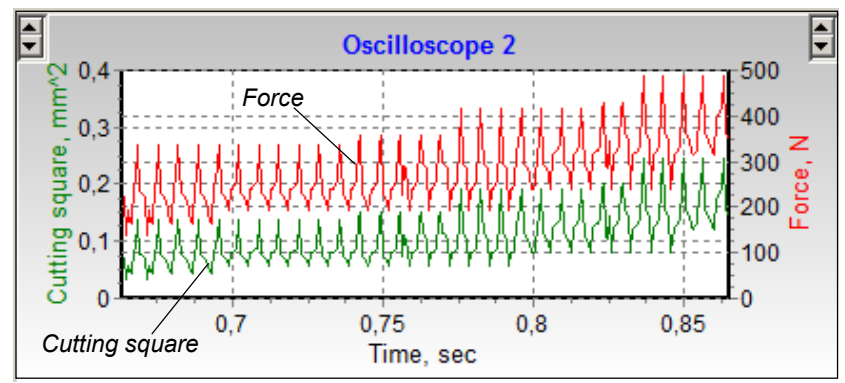

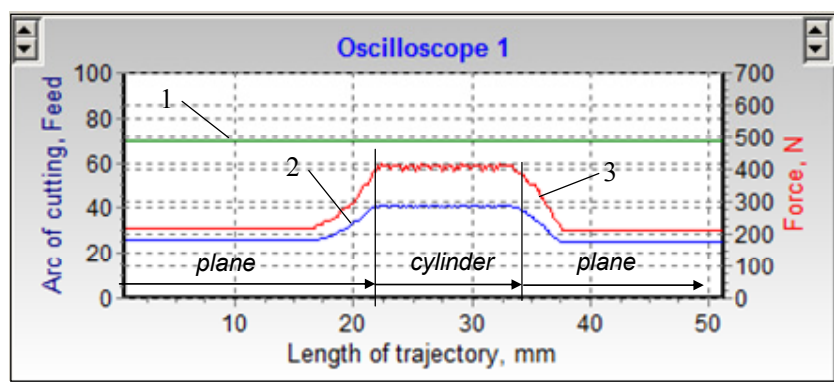

Fig. 3. Simulation results for continuous feed: $a$-oscillograms in time, $b$-integral characteristics in the cycle

The results show that changes in cutting conditions that provoke an appropriate reaction of power characteristics do not coincide with the geometric features by which the control file is designed in iMachining technology. Changing the processing conditions occurs when the center of the cutter moves much earlier than the points of conjugation of the arc with the lines (Fig. 3, $b$ ). And as follows from the iMachining control program in G-codes (see Fig. 1, $b$ ), it is these points that are accepted as reference points in the design of the feed.

After saving the simulation file and calculations according to the formula:

$$
\delta F(l)=\left(\frac{P_{0}}{C_{P} P(l)}\right)^{\frac{1}{\alpha}},
$$

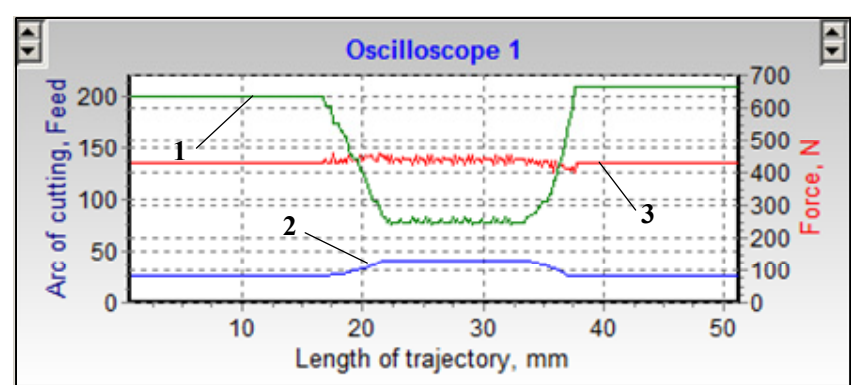

Fig. 4. Simulation results of a milling process with feed control it turns out the feed control law in the function of moving $l$ along the trajectory, which stabilizes the cutting process according to power characteristics.

The simulation results are shown in Fig. 4, where the same notation is used as in Fig. 3, b. In formula (5), $P_{0}$ is the accepted value of the circumferential component of the cutting force during stabilization of the process, and $P(l)$ is the digital array of changes in the component of the cutting force during simulation.

As expected, the designed control provides complete stabilization of the milling process of the contour at $420 \mathrm{~N}$ in terms of the value of the circumferential component of the cutting force, 
although the law of variation of the cutting angle remains the same as in the previous case.

To compare the results of control, according to the control program in G-codes (see Fig.1, $b$ ), it is necessary to generate a feed control file similar in format, which was automatically designed by the iMachining module of the SolidCAM program. The control program assumes an abrupt decrease in the feed rate in frame 134 (see Fig. 1, b) from $2053 \mathrm{~mm} / \mathrm{min}$ to $922 \mathrm{~mm} / \mathrm{min}$ and then also a step increase. It is clear that the machine drives will execute such commands according to their dynamic characteristics. To determine the actual change in feed on the machine, you can imagine the drive model in the form of an aperiodic element of the first order:

$$
W(s)=\frac{k}{T s+1},
$$

where $k$-is a gain, $T$ - is the time constant, $s-$ is the Laplace operator.

The response of such a drive to a stepped control signal is represented by a transition characteristic of the feed change $F(t)$ :

$$
F(t)=\Delta F\left(1-e^{-\frac{t}{T}}\right),
$$

where $\Delta F-$ is the feed jump.

Moving along the shaping trajectory is determined by the integral dependence:

$$
L(t)=\int F(t) d t
$$

The joint solution of equations (7) and (8) gives the dependence of the feed rate change in the function of the coordinate 1 of displacement along the shape-forming trajectory. The solution is conveniently performed numerically; the results are presented in Fig. 5. A step change in feed in the G-code control file occurs at points A and B, and the actual change, taking into account the dynamics of the drive at $\mathrm{T}=0.03 \mathrm{sec}$, is indicated by line 1 . The simulation results in the created program with this control are shown in Fig. 6, where the same designations of the graphs are adopted.

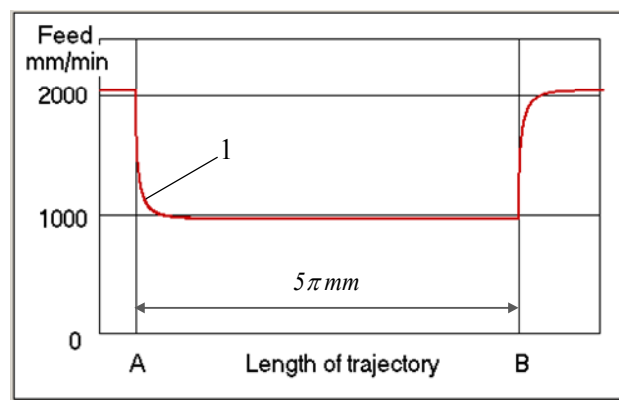

Fig. 5. Schedule of Actual Feed Change

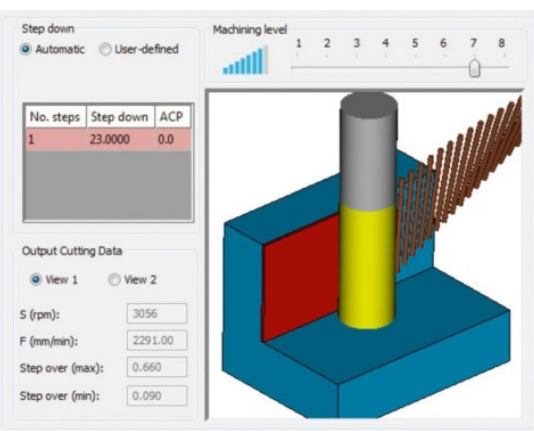

Fig. 7. Technological Machining System stiffness consideration in designing a control program

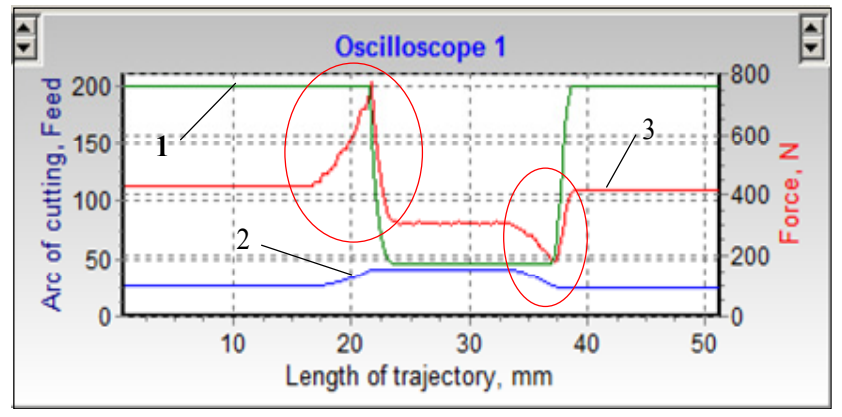

Fig. 6. Simulation results of a milling process with feed control using iMachining technology

Obviously, that this control does not lead to stabilization of the cutting process: in places surrounded by ellipses in Fig. 6, significant changes in the component of the cutting force are observed, which in practice can provoke the appearance of corresponding chatter on the shape of the machined surface. This is due to the adopted strategy, which links the expected changes in cutting conditions to the path of shaping, although, as simulation shows, such changes will occur much earlier and end later, which requires appropriate control based on the results of simulation.

As already noted, the iMachining technologist has adopted a priori control method, where information on the stiffness of the technological processing system is needed to optimize the cutting process. Since such information can only be obtained as a result of experimental studies, the technology decided to preselect one of the possible levels (Fig. 7). Thus, it is proposed to adapt the modeling process to the actual machining conditions. 
However, this solution, although it allows you to take into account real conditions, involves an iterative search of the level based on the results of real machining on CNC machine-tool.

\title{
Conclusions
}

1. The analysis showed that iMachining technology implements the principle of control by a priori information. The module automatically designs feed control using geometrical criteria related to the path of shaping. During optimization, it is proposed to adapt the calculation to real conditions by selecting the stiffness of the technological machining system by choosing one of the levels with further verification of the results in practice.

2. Using the example of designing a control program for machining a test part, it is shown that the approach used in iMachining does not stabilize the cutting process. It is proposed to perform stabilization according to the main characteristic of the cutting process - Material Removal Rate (MRR). This characteristic is obtained as a result of simulation the machining process by a numerical method according to the developed algorithm.

\section{References}

1. Петраков Ю.В. Розвиток САМ-систем автоматизованого програмування верстатів з ЧПУ: Монографія. - К. Січкар, 2011. $-220 \mathrm{c}$.

2. Евченко К., Манчук В. СAM-система PowerMILL 2015 от компании Delcam. Возможности новой версии // Журнал САПР и графика. - 2014. - № 8. - С. 77-79. https://sapr.ru/article/24596

3. Петраков Ю.В. Состояние и перспективы развития САМ-систем в машиностроении // Вісник НТУУ “КПІ". Серія Машинобудування. К.: - 2013.- № 68. - C. 44-54. http://visnyk-mmi.kpi.ua/ru/2013/226-petrakov-y.html

4. Vericut Optipath Module // CGTech. https://doi.org/10.20535/2305-9001.2013.68.33978

5. SolidCAM iMachining // https://www.solidcam.com/ru/imachining/traektorii-imachining/

6. Модуль іMachining // Ж. Высокие технологии. Сайт http://vys-tech.ru/2018/02/02/imachining/

7. Урманов М.Д., Биктимиров Р.А., Насыбуллин Р.К., Хусаинов Р.М. Применение iМachining как модуля высокоскоростной обработки // Ж. Технические науки. - 2017. - Т. 66, № 12. - С. 172-175. www.research-journal.org

8. Петраков Ю.В., Мацківський О.С. Оптимізація периферійного фрезерування кінцевими фрезами // Вісник НТУУ «КПІ». Серія машинобудування. - 2016. - Т. 1, № 76. - С. 88-94.

https://ela.kpi.ua/bitstream/123456789/19585/1/VM_12_Petrakov.pdf

9. Solid CAM. The Leaders in integrated CAM // https://www.solidcam.com/ru/imachining/

10. GARANT Справочник по обработке резанием 857c. // www.garant-tools.com

\section{Анализ технологии iMachining для контурного фрезерования}

\author{
Ю. В. Петраков, А. В. Мигович
}

Аннотация. Признавая практическую необходимость контроля процесса резки, ведущие фирмы на рынке высоких технологий начали предлагать программные продукты, которые, как сообщалось, в автоматическом режиме могли рассчитать оптимальный режим резки. Вот почему возникла необходимость оченки эффективности применения таких инновачий на практике. В настоящее время наиболее продвинутая технология называется iMachining, что означает интеллектуальную обработку. В статье представлен анализ управления, автоматически спроектированного в модуле iMachining Solid CAM, для обработки тестовой детали, контур которой образован двум сопряженными дугой окружности прямыми. Показано, что при проектировании управления используются геометрические критерии, связанные с траекторией формообразования, поэтому стабилизация прочесса резания не достигается. Предлагается метод проектирования управления по результатам моделирования скорости срезания припуска, что позволяет стабилизировать процесс резания.

Ключевые слова: управление резанием, iMachining, стабилизачия MRR, контурное фрезерование на станках с ЧПУ

\section{Аналіз технологій іMachining для контурного фрезерування}

\section{Ю. В. Петраков, А. В. Мигович}

\begin{abstract}
Анотація. Визнаючи практичну необхідність управління процесом різання, провідні фірми на ринку високих технологій почали пропонувати програмні продукти, які, як повідомлялося, в автоматичному режимі могли розрахувати оптимальний режим різання. Ось чому виникла необхідність очінки ефективності застосування таких інновацій на практиці. В даний час найбільш просунута технологія називається іМасhining, шзо означає інтелектуальну обробку. У статті представлений аналіз управління, автоматично спроектованого в модулі іMаchining Solid CAM, для обробки тестової деталі, контур якої утворений двома сполученими дугою кола прямими. Показано, ш⿻о при проектуванні управління використовуються геометричні критерії, пов'язані з траєкторією формоутворення, тому стабілізація процесу різання не досягається.
\end{abstract}


Пропонується метод проектування управління за результатами моделювання швидкості зрізання припуску, що дозволяє стабілізувати процес різання.

Ключові слова: управління різанням, iMachining, стабілізація MRR, контурне фрезерування на верстатах з ЧПУ

\section{References}

1. Petrakov, Y.V. (2011), Rozvitok CAM-systems avtomatizovanogo programuvannia verstativ CNC, Monograph K. Sichkar.

2. Evchenko, K. and Manchuk, V. (2014), "CAM-system PowerMILL 2015 ot companiy Delcam. Vozmognosty novoy versii”, SAPR i graphica, no. 8, pp. 77-79. https://sapr.ru/article/24596

3. Petrakov, Y.V. (2013), Sostoyanie I perspectyvi razvitia CAM-system v mashinostroenii, Journal of Mechanical Engineering NTUU “Kyiv Polytechnic Institute”, no. 68, pp. 44-54. http://visnyk-mmi.kpi.ua/ru/2013/226-petrakov-y.html

4. Vericut Optipath Module, CGTech. https://doi.org/10.20535/2305-9001.2013.68.33978

5. SolidCAM iMachining. https://www.solidcam.com/ru/imachining/traektorii-imachining/

6. Modul iMachining, Visokie technologii. http://vys-tech.ru/2018/02/02/imachining/

7. Urmanov, M.D., Byktimirov, R.A., Nasybullin, R.K. and Yusainov, R.M. (2017), "Primenenie iMachining kak modulia vysocoskorostnoi obrabotky", Tehnicheskie nauki, vol. 66, no. 12, pp. 172-175. www.research-journal.org

8. Petrakov, Y.V. and Mackivsky, O.S. (2016), "Optimizacia pereferiynogo frezerovania kincevymi frezamy", Journal of Mechanical Engineering NTUU "Kyiv Polytechnic Institute”, vol. 76, no. 1, pp. 88-94. http://dx.doi.org/10.20535/2305-9001.2016.76.61261

9. Solid CAM. The Leaders in integrated CAM. https://www.solidcam.com/ru/imachining/

10. GARANT Spravochnik po obrabotke rezaniem. www.garant-tools.com 